\title{
Granulocyte to Total Cell Ratio Measurement
}

National Cancer Institute

\section{Source}

National Cancer Institute. Granulocyte to Total Cell Ratio Measurement. NCI Thesaurus.

Code $C 98866$.

The determination of the ratio of granulocytes compared to total cells present in a sample. The measurement may be expressed as a ratio or percentage. 